\title{
Exploring the Potentials of Banana (Musa Sapietum) Peels in Feed Formulation
}

\author{
Hassan, H. F. ${ }^{1 *}$, Hassan, U. F. ${ }^{2}$, Usher, O. A. ${ }^{3}$, Ibrahim, A. B. ${ }^{2}$ and Tabe, N. N. ${ }^{4}$ \\ ${ }^{1}$ Dass General Hospital, Bauchi State, Nigeria \\ ${ }^{2}$ Department of Chemistry, Abubakar Tafawa Balewa University, Bauchi, Nigeria \\ ${ }^{3}$ Department of Chemical Science, Federal University, Wukari, Nigeria \\ ${ }^{4}$ Department of Chemical Science, Cross River University of Technology, Calabar, Nigeria
}

*Corresponding Author: Hassan, H. F, Dass General Hospital, Bauchi State, Nigeria

Email: hfaroukhassan@gmail.com

\begin{abstract}
The proximate and mineral level of banana (Musa sapietum) peel was determined using standard methods of analyses of AOAC and atomic absorption spectrophotometric method. The peels contained $1.95 \pm$ $0.14 \%$ crude proteins, $5.93 \pm 0.13 \%$ crude fat, $8.37 \pm 0.18 \%$ crude fibre, and $11.82 \pm 2.17 \%$ carbohydrate. The banana peel investigated contained phosphorus $(211.30 \pm 1.24 \mathrm{mg} / 100 \mathrm{~g})$, iron $(47.00 \pm 1.26 \mathrm{mg} / 100 \mathrm{~g})$, calcium ( $59.10 \pm 0.85 \mathrm{mg} / 100 \mathrm{~g})$, magnesium $(44.50 \pm 0.08 \mathrm{mg} / 100 \mathrm{~g})$, sodium $(115.10 \pm 0.26 \mathrm{mg} / 100 \mathrm{~g})$ with low content in zinc $(0.033 \pm 0.04 \mathrm{mg} / 100 \mathrm{~g})$, copper $(0.51 \pm 0.02 \mathrm{mg} / 100 \mathrm{~g})$, potassium $(4.39 \pm 0.15 \mathrm{mg} / 100 \mathrm{~g})$ and manganese $(0.702 \pm 0.09 \mathrm{mg} / 100 \mathrm{~g})$.This shows that the peels can be incorporated in the formulation of animal feed as it contains significant amount of both nutrients and minerals needed for the healthy growth of animals and this will also help in reducing the menace of banana peel waste in the environment.
\end{abstract}

\section{INTRODUCTION}

Banana is one of the most important crops of the tropical plants. It belongs to the family Musaceae and the genus Musa sapientum. It is known in English as banana and in Hausa as ayaba. The plant consists of long, overlapping leaf stalks and bears a stem which is 1.22 to $6.10 \mathrm{~m}$ high (Oladeji et al; 2010). It has life span of about 15 years (Philips, 1982). The fruits grow in clusters, each separate banana of the cluster being about 1 inch in diameter. Banana fruit requires about two and a half to four months after shooting before the fruit becomes ready for harvesting ora total of about eight to twelve months after planting. Banana contains high fibre content, and is capable of lowering cholesterol level and helps to relieve constipation and prevention of colon cancer. Its high potassium content is found to be useful in the prevention of raising blood pressure and muscle cramp. Various parts of the plant such as the leaves, root, fruit stalk, bract and fruit have been used for medicinal and domestic purposes. Its sap is used as a remedy for diarrhoea, dysentery, hysteria and epilepsy. A cold infusion of the root is used to treat venereal diseases and anaemia. In addition, the fruit has been reportedly used as antiscorbutic, aphrodisiac and diuretic. It is known to have originated from tropical region of Southern Asia. It is now cultivated throughout the tropical regions.

Akinsoye, (1991) reported that the plant is cultivated primarily for its fruit and to a lesser extent for production of fibre. It is also believed to be an ornamental plant. The stem which is also called pseudo stem produces a single bunch of banana before dying and replaced by new pseudo stem. The fruit grows in hanging clusters, with 20 fruits to a tie and 3-20 tie to a bunch. The fruit is protected by its peel which is discarded as a waste after inner fleshy portion is eaten. Banana is said to prevent anaemia by stimulating the production of haemoglobin in the blood. Banana is one of the most common crops grown in almost all tropical countries, including Nigeria. Banana plantations occupy a very large part of the country and therefore an abundant and cheap agricultural product. Banana chip and banana fig is the main products from banana flesh produced by a number of small and medium factories located nationwide. As industrial by-products, the peels represent about30-40 g/ $100 \mathrm{~g}$ of fruit weight. This resulted in 200 tons of waste from banana peels generated each day and this amount tends to increase annually (Pangnakorn, 2006). The banana peels waste is normally disposed in municipal landfills, which contribute to the existing environmental problems. The problems can however be overcome by utilizing its high-added value compounds, including the dietary fibre fraction that has a great potential in the preparation of functional foods. Dietary fibre has shown beneficial effects in the prevention of several 
diseases, such as cardiovascular diseases, constipation, irritable colon, colon cancer, and diabetes (Rodriguez et al; 2006).

The fruit fibre has a better quality than other fibre sources due to its high total and soluble fibre content, water and oil holding capacities, and colonic fermentability, as well as a lower phytic acid and caloric value content (Figuerola et al; 2005). The high dietary fibre content of banana peel (about $50 \mathrm{~g} / 100 \mathrm{~g}$ ) is indicative of a good source of dietary fibre (Happi et al;2007). The maturation of banana fruits was reported to impact the dietary fibre composition-contents of banana peels (Happi et al; 2007). However, the peels of banana are thrown away as rubbish and farmers are known to use them as feed for their animals. It is therefore necessary to determine the potassium content of some Nigerian bananas and to also extract the oils from their peels. Banana is eaten all over the world by all sections of the population. It is known to contain potassium and has been suggested that it could serve as a source of potassium (Anhwange, 2008).

Banana peels are used as feedstock as they have some nutritional values. Banana peels are widely used for that purpose on small farms in regions where bananas are grown. There are some concerns over the impact of tannins contained in the peels on animals that consume them (Onwuka et al., 2005). The specific nutrition contained in peels depends on the stage of maturity and the cultivar; for example plantain peels contain less fibre than dessert banana peels, and lignin content increases with ripening (from 7 to $15 \%$ dry matter). On the average, banana peels contain 6-9\% dry matter of protein and 20$30 \%$ fibre (measured as NDF). Green plantain peels contain $40 \%$ starch that is transformed into sugars after ripening. Green banana peels contain much less starch (about 15\%) when green while ripe banana peels contain up to $30 \%$ free sugars (Happi et al., 2007).

The study is aimed at determining the potentials of banana peels (Musa sapietum peels) in feed formulation. The objectives are to evaluate the nutritive (ash, carbohydrate, crude protein, crude lipid, crude fibre and moisture content) and mineral composition (zinc, iron, manganese, sodium, potassium, magnesium, calcium, phosphorus and copper) of the peels of banana.

\section{Materials AND Methods}

In the preparations of all the solutions, chemicals of analytical reagent grade purity and distilled water were used. All the glass and plastic wares were thoroughly washed with detergent solution, repeatedly rinsed with water and the solution to be used therein.

\subsection{Collection of Sample}

Banana fruits were purchased from five (5) different sellers within Bauchi (Wunti and Yelwa markets). The samples were collected, cleaned, washed, dried and stored prior to analysis.

\subsection{Sample Preparation}

Fruits of banana were washed with water, peeled, dried, ground using porcelain pestle and mortar and then sieved using $2 \mathrm{~mm}$ sieve mesh.

\subsection{Determination of Parameters}

Determination of moisture and ash content, crude protein, carbohydrate were made using the methods of AOAC (AOAC; 1990). Energy value crude fat and energy value were done using the methods specified by Ali, (2009) and Hassan et al. (2007) respectively. The minerals: iron (Fe), manganese (Mn), magnesium $(\mathrm{Mg})$, copper $(\mathrm{Cu})$, zinc $(\mathrm{Zn})$, sodium $(\mathrm{Na})$, potassium $(\mathrm{K})$ and calcium $(\mathrm{Ca})$ were determined using Buck Scientific Atomic Absorption Spectrophotometer Model 210 VGP. Determination of phosphorus in the samples were made using the method of Ademoroti (1996).

\section{RESULT AND DIS CUSSION}

\subsection{Result}

Table1. Proximate Composition of Banana Peel

Nutrients

Carbohydrate

Crude Protein

Crude Fiber

Crude Lipid

Moisture Content

Ash Content

Energy (kcal)

Values are the mean \pm standard deviation $(n=5)$

$$
\begin{aligned}
& \% \text { Composition } \\
& 11.82 \pm 2.17 \\
& 1.95 \pm 0.14 \\
& 8.37 \pm 0.18 \\
& 5.93 \pm 0.13 \\
& 62.33 \pm 0.14 \\
& 9.60 \pm 0.02 \\
& 106.50
\end{aligned}
$$


Table2. Mineral Composition of Banana Peel ( $\mathrm{mg} / 100 \mathrm{~g})$

$\begin{array}{lll}\text { MINERAL ELEMENTS } & \text { CONCENTRATIONS } & * \text { RDA }(\mathrm{mg} / 100 \mathrm{~g}) \\ \text { Phosphorus } & 211.30 \pm 1.24 & 270 \\ \text { Magnessium } & 44.50 \pm 0.08 & 170 \\ \text { Sodium } & 115.10 \pm 0.26 & 70 \\ \text { Iron } & 47.00 \pm 1.26 & 35 \\ \text { Calcium } & 59.10 \pm 0.85 & 260 \\ \text { Copper } & 0.51 \pm 0.02 & 0.9 \\ \text { Potassium } & 4.39 \pm 0.15 & 220 \\ \text { Manganese } & 0.702 \pm 0.09 & 3 \\ \text { Zinc } & 0.033 \pm 0.04 & 3\end{array}$

Values are mean \pm standard deviation $(n=5)$.

*Source: (Ramirez-Orduna et al. 2005).

\subsection{Discussion}

Table : 1 shows the results of the proximate nutrient composition of banana peels. The mean percentage moisturelevel of the sample was found to be $62.33 \%$. This value is relatively higher than those obtained in the peels of Plantain 5.43\% (USDA, 2009). High moisture content in foods or its processed products is an indication of its freshness, shelf life and also responsible for greater activity of water soluble enzymes and co-enzymes needed for metabolic activities which subjects food items to increased microbial spoilage and short shelf life, which can lead to its deterioration (Adepoju and Onasanya, 2008).

The peel sample was relatively low in crude protein $1.95 \% \pm 0.14$ when compared with other sources of plant protein. It is however, higher than that of Shea butter fruit pulp (Adepoju and Ketiku, 2003), amaranthus and cocoyam leaves (Adepoju et al; 2006).Protein content of banana peel was low compared with that of other widely eaten stapleroots, tubers and fruits (Aurand, 1987; USDA, 2009) and significantly lower, but higher than that of fluted pumpkin pod and pulp (Essien et al; 1992). Protein is an essential component of diet needed for survival of animals andhuman being, their basic function in nutrition is to supply adequate amount of required amino acids.

The crude fat content of the peels of banana was low $(5.93 \% \pm 0.13)$ and may therefore not be a good source of fat soluble vitamins, but can contribute significantly to energy content of the feeds. Their low fat content will increase the storage life of the flour by reducing the chances of developing rancidity (Okareh et al; 2015). The ash content of the sample $(9.60 \% \pm 0.02)$ was comparatively higher than those reported by previous researchers for agricultural hull (0.50-4.40\%) (Adebowale and Bayer, 2002) and plantain peels (7.83 \pm 0.58$)$ (Adeyi and Oladayo, 2010). The high values of the ash are indicative of high mineral (especially the macro minerals) content of the peels.

The banana peel investigated was high in crude fibre $(8.37 \% \pm 0.18)$. This falls within the range of $(8.50 \%-20.90 \%)$ for some Nigerian vegetables (Isong and Idiong, 1997). The value also compared well to that of reported value obtained from plantain peels $(10.4 \% \pm 0.6)$. High fibre content in diets have been reported to result in increased removal of potential mutagens, steroids and xenobotics by binding or absorbing to dietary fibre components and thereby aids digestion; hence these wastes will therefore have health promoting benefits for livestock and fish farming (Eleazu et al; 2015). The sample was high in carbohydrate content $(11.82 \% \pm 2.17)$ which implies good source of energy for animals. This value was found to be higher than that of scent leaves (1.22\%) and Telfaira occidental $(1.16 \%)$, (Asaolu et al; 2012). Carbohydrate constitutes a major class of naturally occurring organic compounds (Hassan et al; 2013).

The energy content of the banana peel calculated was $106.50 \mathrm{kcal}$, this value is low compared to those of Moringa olefeira seeds (1920.10 KJ/100 g), (Hassan et al; 2013).

Table 2 shows the mineral contents of the peel of banana (Musa sapietum). The peels were high in sodium, phosphorus, and iron but low in potassium, manganese, copper and zinc. The peel can be good sources of sodium, phosphorus and iron. Calcium $(59.10 \mathrm{mg} / 100 \mathrm{~g})$ and phosphorus $(211.30 \mathrm{mg} / 100 \mathrm{~g})$ are very important in the formation of strong bones and teeth, useful for growth, blood clotting, heart function and cellmetabolism (Roth and Townsend, 2003; Rolfe et al; 2009). Calcium is an important component of intracellular processes that occur within insulin responsive tissues like skeletal muscle and adipose tissue. Alteration in calcium flux can have adverse effects on insulin secretion which is a calcium-dependent process (Connell, 2001). 
Phosphorus is involved in several biological processes such as: bone mineralization, energy production, cell signaling and regulation of acid-base homeostasis. Deficiency in calcium and phosphorus in animals will therefore result in impaired bone mineralization, reduced bone strength and poor growth (Eleazu et al; 2015). Potassium level was found to be $4.39 \mathrm{mg} / 100 \mathrm{~g}$. This is an important raw material in soap production and in soil neutralization (Adeolu and Enesi, 2013). It is an essential element that helps in the development of the body and muscle. The iron level of the peel $47.00 \mathrm{mg} / 100 \mathrm{~g}$ was higher than the values recorded for dry guinea corn leaf extracts $(1.20 \mathrm{mg}-2.10 \mathrm{mg} / 100 \mathrm{~g}$ ), (Adepoju, 2007) and fresh and roasted Dacryodes edulis fruit, $(7.0 \mathrm{mg}$ and $3.0 \mathrm{mg} / 100 \mathrm{mg}$ respectively) (Adepoju and Adeniji, 2008).Iron is an essential component of hemoglobin and it is critical to the proper functioning of the immune system and the production of energy (Chen et al., 2010).

The mean magnesium content was found to be $44.50 \mathrm{mg} / 100 \mathrm{~g}$. This value is higher compared to magnesium content in Dioscorea alata peel, (10.30 \pm 1.04), (Yahaya et al; 2007). Magnesium is largely $(80.00 \%)$ protein bound and is associated predominantly with the microsomes, where it functions as a catalyst of a wide array of enzymes, facilitating the union of substrate and enzyme by first binding to one or the other (Ebel and Günther, 1980). Magnesium is thus required for oxidative phosphorylation leading to ATP formation, sustaining processes such as the sodium ion/potassium ion pump; pyruvate oxidation and conversion of a-oxoglutarate to succinyl coenzyme A; phosphate transfers, including those affected by alkaline phosphatase.

The mean zinc level was found to be $0.51 \mathrm{mg} / 100 \mathrm{~g}$. There was no significant difference compared to the value obtained in Dioscorea alata peel (Yahaya et al; 2007). Zinc plays a key role in the regulation of insulin production by pancreatic tissues and glucose utilization by muscles and fat cells (Eleazu et al; 2013).

The level of copper was found to be $0.03 \mathrm{mg} / 100 \mathrm{~g}$. The value obtained shows no significant difference compared to the value obtained in Dioscorea alata peel (Yahaya et al; 2007). Copper is present in all living organisms and is a crucial trace element in redox chemistry, growth and development. Copper is being explored as treatment for a number of conditions, including degenerative neurological disorders like Alzheimer's disease, Parkinson's disease (Tisato et al; 2010). The mean composition of sodium in banana peel was found to be $115.10 \pm 0.26 \mathrm{mg} / 100 \mathrm{~g}$. This value was found to be lower than that of Vitexdoniana leaves with $53.2 \mathrm{mg} / \mathrm{kg}$ (Chindo et al; 2009). Sodium helps in maintaining healthy fluid balance (Tisato et al; 2010). The mean value of manganese determined was found to be $0.70 \pm 0.09$ $\mathrm{mg} / 100 \mathrm{~g}$. Manganese also plays a role in fat, amino acid and carbohydrate metabolism, calcium absorption, and blood sugar regulation. It is also necessary for normal brain and nerve function.

\section{CONCLUSiON}

The banana peel wastes were rich in crude fibre, carbohydrates, crude protein and ash and can serve as basal materials or components of animal feed. The wastes were high in calcium, phosphorus, magnesium and iron, and can be good source of these minerals. Banana peel wastes pose to be potential good sources of nutrients for production of animal feeds, and their utilization for this purpose should be encouraged, as this will also help in reducing the menace of banana peel waste in the environment. The study underscores the nutritional relevance and mineral potentials of the peels of banana. The banana peel can be sources of nutrients in animal feed preparation, as they are high in protein, fibre and essential mineral content. This will result in dual benefits of its use as animal feeds and proper banana wastes management (waste reduction) strategy, as the wastes would have constitute nuisance to the environment.

\section{REFERENCES}

Adebowale, K.O. and Bayer, E. (2002): Active carbons from low temperature conversion chars. Electronic J. Environ. Agric. Food Chem.7 (11): 3304-3315.

Adeniji, T.A. and Empere, C.E. (2001): The development, production and quality evaluation of cake made from cooking banana flour. Global journal of Pure and Applied Science. 7(4): 633.

Ademoroti, C.M.A. (1996): "Standard Methods for water and effluents analysis". Foludex press.pp 71-78.

Adepoju, O.T. and Adeniji, P.O. (2008): Nutrient composition, anti-nutritional factors and contribution of native pear (Dacryoidesedulis) pulp to nutrient intake of consumers. Nig J Nutr. Sci. 29(2): 15 - 23.

Adeolu, A.T. and Enesi, D.O. (2013): Assessment of proximate, mineral, vitamin and phytochemical compositions of plantain (Musa paradisiaca) bract in agricultural waste. Int. Res. J. of Plant Science.4 (7): 192-197.

Adeyi, Oladayo (2010): Proximate composition of some agricultural wastes in Nigeria and their potential use in activated carbon production. J. Appl. Sci Environ. Manage. 14(1), 55-58. 
Ali, A. (2009): Proximate and mineral composition of the marchubeh (Asparagus officinalis). World Dairy and Food Science.4 (2): 142-149.

Anhwange, B.A. (2008): Chemical Composition of Musa sapientum (banana) peels. J Food Tech.6: 263-6.

AOAC (2000): Official Method of Analys is of the AOAC 15th Edition, Washington D.C. Pp.17.

Chen, X.H., Xia, L.X., Zhou, H.B. and Qiu, G.Z. (2010): Chemical composition and antioxidant activities of Russulagriseocarnosa sp. nov. J.Agric Food Chem. 58: 6966-6971.

Chindo, I.Y., Wufem, B. M., Gushit, J. S. and Olotu, P. N. (2009): Nutritional Composition of Vitexdoniana (black plum) fresh leaves. Journal of Chemical Society of Nigeria.34 (2): 123-125.

Essien, A.I., Ebana, R.U.B. and Udo, H.B. (1992): Chemical evaluation of pod and pulp of the fluted pumpkin (Telfairaoccidentalis) fruit. Food Chem. 45: 175-178.

Ebel, H. and Gunther, T. (1980): Magnesium metabolism review. Journal of Clinical Chemistry and Clinical Biochemistry. 18: 257-270.

Eleazu, C.O., Iroaganachi, M. and Eleazu K.C (2013): Ameliorative potentials of cocoyam (Colocasiaesculenta L.) and unripe plantain (Musa paradisiaca L.).J. of Diabetes Reserch.Article ID 160964: 8 pages.

Eze, S.O. andIbe, O.J. (2004): Effects of fermentation on the Nutritive Value of B. eurycoma "ACHI".J. Chem.Soc.Nigeria.30 (1): 55-58.

Figuerola, F., Hurtado, M.L., Estevex, A.M., Chiffelle, I. and Asenjo, F. (2005): Fibre concentrates from apple pomace and citrus peel as potential fibre sources for food enrichment. Food chemistry.9: 395-401

Hassan, L.G., Umar K.J., and Tijjani A.A. (2007): Preliminary Investigation on the feed quality of Monechmaciliatum seeds. Chem Class journal.4:83-86.

Hassan, U.F., Baba, H., Shibdawa, M.A., Mahmoud, A.A. and Ishaku J. (2013): Assessment of feed quality efficiency of Moringaoleifera seeds. J.S.C.N.38 (2): 70 - 73.

Okaka, J.C.,Akobundu E.N. andOkaka A.N. (2002): Human Nutrition: An Integrated Approach"e, 2nd Ed. O. C. Janco Academic publishers. 26: 45.

Onwuka, G.I. (2005): “Food analys is Instrumentation. Theory and Practice”.Naphthaliprints. 140-146.

Ramerez-Orduna, R., Ramirez, R.G., Gonzalez-Rodriguez and Haelin, G.F.W. (2005): In:Hassan, L.G., Umar K.J., and Tijjani A.A. (2007): Preliminary Investigation on the feed quality of Monechmaciliatum seeds. ChemClass journal.4:83-86.

Rodriguez, S.D., Hadley, M. and Holm, E.T. (1994a): Potato peel waste stability and antioxidant activity of freeze dried extract. Journal of Food Science.59: 1031-10.

Rolfes, S.R., Pinna, K. and Whitney, E. (2009): "Understanding normal and clinicalnutrition".J.Sci. Food. 36: 118- 122.

Roth, A.R.and Townsend C.E. (2003): Nutrition and diet therapy 8th edn.Delmar Learning, Thomson Learning Inc. Canada.Pp 132 and cover page

Tisato, F.,Marzano,T.,Porchia, M. and Pellei, M.C. (2010): Copper in diseases and treatments, and copper-based anticancer strategies on the relative tissue weights of streptozotocin-induced diabetic rats. Journal of Diabetes Research.Article ID 160964, 8 pages.

USDA (2009): National Nutrient Database for Standard Reference, Release 22. http://www.nal.usda.gov/ fnic/foodcomp/plantain/.Accessed on 6/2/2012.

Yahaya, I.A., Nok, A.J., Saidu, S.A., Achi, S.S. and Bonire, J.J. (2007): Nutritional and Anti-nutrional Assessment of the Peel of Dioscoreaalata (water yam). ChemClass Journal. 4:65-69.

Citation: Hassan et al., "Exploring the Potentials of Banana (Musa Sapietum) Peels in Feed Formulation", International Journal of Advanced Research in Chemical Science (IJARCS), vol. 5, no. 5, pp. 10-14, 2018. http://dx.doi.org/10.20431/2349-0403.0505003

Copyright: (C) 2018 Authors. This is an open-access article distributed under the terms of the Creative Commons Attribution License, which permits unrestricted use, distribution, and reproduction in any medium, provided the original author and source are credited. 